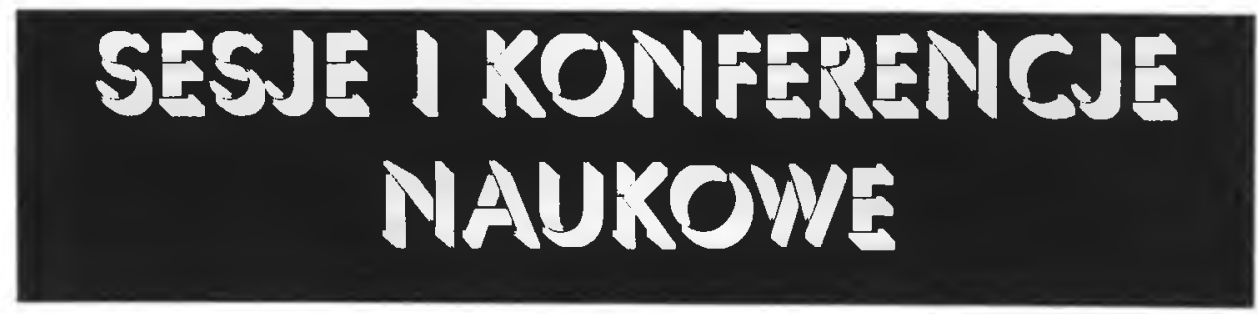

\title{
Sprawozdania
}

\section{Międzynarodowy Kongres Historyków Wychowania Berlin 13-17.09.1995 r.}

Zgodnie z planem - International Standing Conference for the History of Education (ISCHE) - obradował w Berlinie w siedzibie Freie Universität (FU) i w Uniwersytecie Humboldta, 17 juz, doroczny międzynarodowy kongres historyków wychowania.

Kongres zgromadzil ok. 200 uczestników i osób towarzyszących ze wszystkich kontynentów. Reprezentowali oni następujące państwa: Afrykę Poludniową, Algerię, Argentynę, Australię, Austrię, Belgię, Brazylię, Bułgarię, Chińską Republikę Ludową, Danię, Finlandię, Francję, Grecję, Hiszpanię, Holandie, Hongkong, Iralndię, Izrael, Japonię, Kazachstan, Kanadę, Litwę, Meksyk, Niemcy, Nigerię, Norwegię, Polskę, Portugalię, Rosję, Stany Zjednoczone, Szwecję, Szwajcarię, Tajwan, Uzbekistan, Wielką Brytanię, Węgry, Włochy.

Uczestnicy przygotowali ponad 150 referatów, które były wygłaszane podczas realizacji różnych form obrad kongresu, a mianowicie w czasie posiedzeń plenarnych, w czasie obrad grup seminaryjnych, na zebraniach otwartych grup roboczych (open working groups), na posiedzeniach okraglego stołu w trakcie prac stałych grup roboczych działających przy ISCHE.

$Z$ referatów plenarnych szczególnym zainteresowaniem cieszyło się wystąpienie prof. dra Heinza-Elmara Tenortha, znanego metodologa niemieckiego, obecnie z Uniwersytetu Humboldta w Berlinie, pt: Geschichte der Erziehungswissenschaft: Konstruktion einer Chimāre oder Historie einer Karriere? Temat sformulowany dość enigmatycznie, ale i romantycznie brzmiący. W takich sformułowaniach lubują się przedstawiciele niemieckich nauk humanistycznych.

Wykład prof. Tenortha był wystąpieniem plenarnym, rzec można globalnym, przeznaczonym dla wszystkich uczestników. Obok tego, były także referaty plenarne równoległe z możliwościami alternatywnego wyboru, np. prof. prof. Rủdigera von Brucha (z Uniwersytetu Humboldta), Petera Drewka (FU - Berlin), Antonio Novoa (Uniw. w Lizbonie), Thomasa Popkewitza (Uniw. Wiscjonsin-Madison), Mitchella G. Asha (Uniw. Iowa), Marca Depaepe (z Katolickiego Uniwersytetu w Leuven), Teruhisa Horio (Uniw. w Tokio), Júrgena Schriewera (Uniw. Humboldta) i in.

Odbyły się również posiedzenia następujących stałych grup roboczych działających przy ISCHE: International Standing Working Group on Gender and the History of Education działająca od 1989 r., tj. od 11 kongresu w Oslo; International Standing Working Group for the History of Education and Enlightenment, działającej od 1985 r., tj. od 7 kongresu w Salamance; International Standing Working Group for the History of Education as a Field of Research and Teaching Subject, działająca od 1990 r., tj. od 12 kongresu w Pradze. W Berlinie nie odbyło się posiedzenie najdłuziej działajacej grupy roboczej: International Standing Working Group for the History for Childhood Education, która powstała w Bambergu już w 1984 r., tj. w okresie obrad 
6 kongresu ISCHE w Wolfenbüttel. Grupa ta spotkała się na posiedzeniu naukowym w bieżącym roku również w Bambergu.

Nad obradami kongresu przewijało się larum prof. dra Teruhisa Horio z Uniwersytetu w Tokio, który w swym referacie plenarnym pt.: The Emergence and Development of Educational Studies in Modern Japan ostrzegał, iż nasza konsumpcyjna codzienność powoduje na całym świecie wielkie niebezpieczeństwa i zagrożenia dla rozwoju nauk humanistycznych, w tym i nauk o wychowaniu.

Warto wspomnieć, iż mimo permanentnych problemów natury finansowej 12 polskich pracowników naukowych wzięło udział w kongresie, w tym znaczna liczba młodych adeptów nauki. Dla części z nich był to pierwszy udział w kongresie międzynarodowym. Polscy pracownicy naukowi znaleźli się na trzecim miejscu pod względem liczby uczestników po Niemcach (16), Hiszpanach (13) i Anglikach (13).

Wszyscy Polacy byli niezwykle aktywni i przygotowali nastepujące referaty: Bogusław Chmielowski (Akademia Wych. Fizycznego - Katowice), pt. Die Kulturpādagogik von Bogdan Suchodolski (1903 - 1992); Joanna Elżbieta Dąbrowska (Filia UW w Białymstoku) pt. Image of the Faculty: A Year After; Adam Fijalkowski (UW) pt. Auxiliary Scholar Disciplines of History of Education studies; Wlodzimierz Goriszowski (WSP Kielce - Filia w Piotrkowie Tryb.) pt Elements of Managerial Conceptions in teaching of School Management Staff; Jan Hellwig (UAM-Poznañ) pt. Die Forschungen über Geschichte der Erziehung in Poznań; Czesław Majorek (WSP-Kraków) pt. Herbartian Educational Theory in the Ninetecnth Century. Polish Teacher Seminars; Lech Mokrzecki i Józef Zerko (UG) pt. Regionalism in Scientific Research and in the Program of Teaching, History of Education in Poland; Ewa Romanowska (Filia UW w Bialymstoku) pt. Education as a Factor in the Development of Belorussian Culture in Poland; Joanna Katarzyna Sadowska (Filia UW w Białymstoku) pt. The Educational Reform of 1932 in Poland.

W kongresie uczestniczyli także prof. prof. Teresa Wróblewska i Lucjan Olszewski (oboje WSP Kielce, Filia w Piotrkowie Trybunalskim).

Polskie referaty i zawarta $w$ nich problematyka głównie o akcentach narodowych, cieszyły się dużym zainteresowaniem. Wynikalo to także $\mathrm{z}$ tego, że następny 18 kongres ISCHE odbędzie się w Polsce, w siedzibie WSP, w Krakowie, w dniach od 6 do 9 sierpnia 1996 r. a jego temat został sformułowany następująco: Schooling in changing societies. Historical and comparative perspectives (c. 1750 - 1996).

Kongres dokonał swoistego historycznego przeglądu rozwoju nauk o wychowaniu. Mimo wspomnianego wołania na trwoge zarysowany obraz wydaje się być optymistyczny. Na uwage zasługiwały ewidentne postępy w rozwoju nauk o wychowaniu w poszczególnych krajach, regionach kulturowych a nawet na kontynentach. Brak było jednak syntez holistycznych, które w moim przekonaniu mogłyby w pewnym sensie powstać, gdyby wykorzystać całość materiałów referatowych przedstawionych na kongresie. Organizatorzy wydali jednak jedynie abstrakty. Przydatna byłaby publikacja pełnych materiałów, co jednak ze względów finansowych prawdopodobnie nie nastąpi.

Jan Hellwig

\section{Spotkanie naukowe historyków wychowania przedszkolnego Bamberg (RFN) 9-12.09.1995 r.}

Dwunaste już międzynarodowe spotkanie naukowe historyków wychowania przedszkolnego odbyło się tym razem w malowniczym mieście bawarskim Bambergu.

Głównym problemem przewijającym się zarówno w referatach dyskusji, wystawach opracowań było analizowanie zagadnienia „Do kogo należy dziecko? Od 1800 r. do czasów wspólczesnych" (,To whom does the young child belong? 1800 till the present"). 